\title{
Perlakuan Benih Padi Yang Disimpan Dengan Pestisida Nabati Sereh Wangi Terhadap Hama Bubuk Padi (Sitophilus oryzae L.)
}

\author{
Mira Herawati Soekamto, Zainuddin Ohorella, John Rivan Ijie*) \\ ${ }^{*}$ Fakultas Pertanian Universitas Muhammadiyah Sorong \\ email: mirasoekamto@um-sorong.ac.id
}

\begin{abstract}
Abstrak
Penelitian ini bertujuan untuk mengetahui kemampuan dari pestisida nabati bubuk sereh wangi sebagai seedtreatment pada benih padi yang disimpan terhadap hama bubuk padi Sitophylus oryzae. Penelitian ini menggunakan metode eksperimen dengan menggunakan Rancangan Acak Kelompok (RAK). Faktor perlakuan yang diujikan adalah bubuk sereh wangi yang terdiri dari 3 taraf, yaitu bubuk sereh wangi 2,5 gr/100 gr benih padi (S1), bubuk sereh wangi 5 gr/100 gr benih padi (S2), bubuk sereh wangi 7,5 gr/100 gr benih padi (S3). Perlakuan ini diulang sebanyak 5 kali, dengan demikian terdapat 15 satuan perlakuan. Setiap satuan perlakuan terdiri atas 20 ekor serangga uji. Berdasarkan hasil penelitian yang telah dilakukan, semua perlakuan dosis bubuk sereh wangi mampu mematikan hama bubuk Sitophilus oryzae sejak dari hari ke-5 setelah aplikasi sampai hari ke-3O setelah aplikasi. Perlakuan dosis bubuk sereh wangi 7,5 gr/100 gr benih padi, merupakan dosis bubuk sereh wangi yang terbaik dalam meningkatkan rata-rata persentase mortalitas hama bubuk Sitophilus oryzae. Sampai pada waktu pengamatan hari ke-30 setelah aplikasi, menghasilkan rata-rata. Selain itu, perlakuan dosis bubuk sereh wangi 7,5 gr mampu menurunkan persentase kehilangan berat akhir dari benih padi, dimana sampai pengamatan hari ke-30 setelah aplikasi kehilangan berat benih padi hanya sebcsar 30,7\%. Sedangkan persentase kehilangan bobot akhir benih padi yang tertinggi dihasilkan oleh perlakuan dosis bubuk sereh wangi 2,5 gram, dimana sampai hari ke-30 setelah aplikasi persentase kchilangan berat benih padi sebesar $64,1 \%$.
\end{abstract}

Kata kunci: Hama, Padi, Pestisida, Sitophilus oryzae

\section{PENDAHULUAN}

Kebutuhan beras secara nasional terus meningkat seiring dengan meningkatnya jumlah penduduk. Produksi padi di Indonesia pada tahun 2009 sekitar 51,20 juta ton, sedangkan kebutuhan padi pada tahun 2025 diperkirakan meningkat hingga mencapai 70 juta ton. Menurut Prasetyo (2011), peningkatan padi nasional harus benar-benar dipacu agar dapar mencapai tingkatan yang diperlukan untuk memenuhi kebutuhan beras yang terus meningkat.

Penyimpanan beras dan bahan pangan lain merupakan salah satu mata rantai kegiatan pasca panen sebeum komoditas di distribusikan. Kehilangan komoditas berupa 
menurunnya mutu, bertambhnya kadar air, kotoran benda asing, kerusakan bentuk, warna, bau, rasa,dan kehilangan berupa penyusutan berat harus diperhatikan selama penyimpanan (Hendra, 2012). Menurut FAO, kehilangan hasil panen di negara-negara berkembang berkisar antara 10-13\%, diantaranya berkisar 5\% oleh berbagai jenis hama gudang seperti serangga, tikus, tungau, burung, dan jasad renik. Bulog memperkirakan susut bobot beras sekitar $25 \%$, terdiri dari $8 \%$ waktu panen, $5 \%$ waktu penganngkutan, $2 \%$ pengeringan, $5 \%$ waktu penggilingan, dan $5 \%$ waktu penyimpanan (Rukmana, 2007).

Bahan-bahan (produk pertanian) yang disimpan didalam gedung terbuka ataupun tertutup tetap akan memperoleh gangguan berupa hama, tetapi gangguan hama terhadap bahan-bahan yang ada digudang tertutup biasanya lebih sedikit jika dibandingkan dengan bahan yang disimpan digudang terbuka. Cara pengendalian dan pemberantasan hama yang ada digudang tertutup lebih mudah dan lebih meyakinkan jika dibandingkan dengan bahan-bahan yang masih ada digudang terbuka (Anggara, 2011).

Menurut Yasin (2009), terdapat sekitar 20 jenis serangga yang terdapat pada bahan pangan yang disimpan di gudang, namun hanya sebagian yang penting. Beberapa serangga seperti kupu-kupu gabah (Sitotroga cerealella), kumbang beras (Sitophylus oryzae), dan kumbang jagung (Sitophylus zeamays) sudah dapat menyerang padi atau jagung di lapang untuk kemudian berkembang biak di gudang. Sitophylus oryzae merupakan salah satu hama penting dalam gudang. Selama perkembangan dari telur sampai imago dapat menurunkan produksi sampai $20 \%$ dalam waktu 5 minggu (Pracaya, 2011). Faktor yang menentukan derajat kesrusakan beras oleh Sitophylus oryzae dalam masa penyimpanan antara lain oleh pengaruh populasi, varietas asal beras, serta lama penyimpanan beras.

Kumbang bubuk beras Sitophylus oryzae atau Calandra oryzae, merupakan hama utama pada beras yang disimpan. Serangannya ditandai dengan butir beras berlubanglubang atau menjadi tepung karena gerekan kumbang. Akibat hama ini beras dapat kehilangan berat hingga 23\% setelah disimpan beberapa bulan (Heri dan Asih, 1995). Secara alami kecenderungan hama dalam memilih makanan banyak dipengaruhi oleh beberapa faktor, faktor tersebut antara lain jenis dan kerusakan bahan simpan, nilai gizinya, kadar airnya, warna, dan tingkat kekerasan kulit (Anggara, 2011).

Untuk mengatasi masalah ini perlu dilakukan pengendalian hama Sitophylus oryzae. Cara yang banyak digunakan adalah menggunakan insektisida kimia sintetik. Penggunaan insektisida kimia sintetik cukup efektif, tetapi menimbulkan permasalahan berupa residu pada padi dan beras. Tentunya hal ini sangat berbahaya karena residu tersebut bersifat karsiogenik.

Salah satu alternatif pengendalian Sitophylus oryzae yang efektif dan efisien serta tidak menimbulkan efek samping terhadap bahan simpanan benih padi dan beras selama penyimpangan adalah dengan menggunakan biopestisida yaitu pestisida nabati. Penggunaan pestisida nabati berbahan tanaman atsiri mulai dikembangkan karena diketahui cukup efektif dalam mengendalikan beberapa organisem pengganggu tanaman (OPT). Minyak atsiri dari tanaman rempah dan obat (TRO) diketahui mengandung 
senyawa aktif yang dapat digunakan sebagai bahan baku insektisida. Hal ini berkaitan dengan sifatnya ynag mampu membunuh, mengusir, dan menghambat makan hama, serta mengendalikan penyakit tanaman (Oka, 2003).

Salah satu pestisida nabati yang dapat digunakan untuk mengendalikan hama bubuk padi (Sitophylus oryzae) adalah tanaman sereh wangi. Menurut hasil penelitian Wiratno dkk (2011), minyak sereh wangi dapat menyebabkan mortalitas Dasymus hewettti (hama pengisap bunga lada) sebesar $47 \%$ pada konsentrasi 2,5\% dan gabungan minyak sereh wangi dan lengkuas (1:1) pada konsentrasi 2,5\% mampu menyebabkan mortalitas sebesar $82 \%$. Selanjutnya menurut Sastrahamidjojo (2004), minyak sereh wangi mengandung 3 komponen utama yaitu sitronelol dan geraniol. Kandungan utama minyak atsiri dari sereh wangi terdiri dari komponen sitronelal 32-45\%, geraniol 12 $18 \%$, sitronelol 11-15\%, geranil asetat 3-8\%, sitronelil asetat 2-4\%, sitral, kavikol, eugenol, elemol, kadinol, kadinen, vanilin, limonen, dan kamfen.

Sehubungan dengan kandungan minyak atsiri dari tanaman sereh wangi dapat digunakan untuk mengendalikan hama tanaman, maka perlu dikaji lagi potensi konsentrasi ekstrak sereh wangi untuk mengendalikan hama bubuk padi (Sitophylus oryzae) pada benih padi yang disimpan. Berdasarkan hal tersebut, maka penelitian ini bertujuan untuk mengetahui kemampuan dari pestisida nabati bubuk sereh wangi sebagai seedtreatment pada benih padi yang disimpan terhadap hama bubu padi Sitophylus oryzae.

\section{METODE PENELITIAN}

Penelitian ini menggunakan metode eksperimen dengan menggunakan Rancangan Acak Kelompok (RAK). Faktor perlakuan yang diujikan adalah bubuk sereh wangi yang terdiri dari 3 taraf, yaitu bubuk sereh wangi 2,5 gr/100 gr benih padi (S1), bubuk sereh wangi $5 \mathrm{gr} / 100$ gr benih padi (S2), bubuk sereh wangi 7,5 gr/100 gr benih padi (S3). Perlakuan ini diulang sebanyak 5 kali, dengan demikian terdapat 15 satuan perlakuan. Setiap satuan perlakuan terdiri atas 20 ekor serangga uji, dengan demikian jumlah serangga uji Sitophylus oryzae yang digunakan sebanyak 300 ekor.

\section{Pelaksanaan Penelitian}

\section{Pembiakan Masal Hama Sitophylus oryzae L.}

Untuk mendapatkan jumlah imago (serangga dewasa) hama Sitophylus oryzae L. sesuai kebutuhan maka pengambilan imago jantan dan betina diambil pada beras yang berada di gudang beras (bulog) atau toko sembako yang kemudian dipelihara dengan cara imago Sitophylus oryzae L. dimasukkan kedalam botol selai atau kotak plastik yang didalamnya telah disediakan beras sebagai pakan dari serangga hama ini. Setelah hama berkembang biak dalam wadah pemeliharaan, selanjutnya digunakan sebagai serangga uji untuk penelitian. Proses pembiakan masal hama ini dilaksanakan selama 3 minggu. 


\section{Pengambilan Tanaman Sereh Wangi untuk Pestisida Nabati}

Untuk mendapatkan bubuk sereh wangi yang akan digunakan sebagai pestisida, diawali dengan pengambilan tanaman sereh wangi dari lapangan sebanyak 500 gram kemudian dicuci untuk menghilangkan kotoran yang menempel pada tanaman tersebut. Selanjutnya tanaman sereh wangi dikering anginkan selama satu minggu untuk mendapatkan bobot kering yang kosntan. Setelah masa pengeringan, kemudian tanaman sereh wangi dapat digunakan.

\section{Pembuatan Pestisida Bubuk Tanaman Sereh Wangi}

Tanaman sereh wangi yang telah dikering anginkan selanjutnya dipotong-potong hingga berukuran kecil, kemudian digiling sampai halus dan diayak untuk mendapatkan serbuk atau bubuk. Selanjutnya ditimbang sesuai konsentrasi perlakuan yang akan diujikan, dan kemudian dimasukkan kedalam wadah satuan perlakuan (botol selai atau kotak plastik) dan dibiarkan semalam.

\section{Pengujian Pestisida Bubuk Tanaman Sereh Wangi}

Benih padi sebagai pakan hama Sitophylus oryzae ditimbang sebanyak 100 gram, kemudian dimasukkan kedalam botol selai atau kotak plastik yang didalamnya telah tersedia bubuk sereh wangi sesuai dengan perlakuan yang diujikan. Bubuk sereh wangi dan benih padi yang terdapat dalam setiap satuan perlakuan selanjutnya ditambahkan air sebanyak $20 \mathrm{ml}$, kemudian diaduk sampai rata (homogen). Selanjutnya hama bubuk padi Sitophylus oryzae dimasukkan sebanyak 20 ekor untuk setuap perlakuan dengan membandingkan sex ratio yang jantan dan betina dengan perbandingan 3:1, kemudian disimpan untuk tujuan pengamatan.

\section{Variabel Pengamatan}

\section{Persentase Mortalitas Hama Bubuk Padi}

Pengamatan terhadap persentase mortalitas hama bubuk padi dilaksanakan pada hari ke 5, 10, 15, 20, 25, dan 30 setelah aplikasi (HSA). Persentase mortalitas hama bubuk padi dihitung dengan menggunakan rumus yang dikemukakan oleh Natawigena (2007).

$$
\mathrm{P}=\frac{\mathrm{n}}{\mathrm{N}} \times 100 \%
$$

Dimana $: \mathrm{P} \quad=$ Persentase mortalitas

$\mathrm{n} \quad=$ Jumlah individu yang mati

$\mathrm{N} \quad=$ Jumlah individu yang digunakan

2. Persentase Kehilangan Berat Benih Padi

Perhitungan persentase kehilangan berat benih padi dari berat awal akibat serangan hama bubuk padi dilakukan pada 30 hari setelah aplikasi (HSA) bubuk sereh wangi dengan menggunakan rumus yang dikemukakan oleh Martono (2009).

$$
\mathrm{BB}=\frac{\mathrm{BBA}-\mathrm{BAB}}{\mathrm{BBA}} \times 100 \%
$$

Dimana $: \mathrm{BB}=$ Berat benih yang hilang

$\mathrm{BBA}=$ Berat benih awal

$\mathrm{BAB}=$ Berat akhir benih 


\section{Median Volume 11 Nomor 2 Bulan Juni 2019}

Doi http://doi.org/md.v11i2.550

\section{Analisis Data}

Hasil penelitian selanjutnya dianalisis dengan menggunakan analisis keragaman (ANOVA), jika terdapat perlakuan yang berpengaruh nyata terhadap satuan uji maka dilanjutkan dengan Uji Beda Nyata Jujur (BNJ) pada tingkat kepercayaan 5\%.

\section{HASIL DAN PEMBAHASAN}

\section{Hasil Penelitian}

\section{Persentase Mortalis Hama Sitophilus oryzae Dan Pengaruh PerLakuan Bubuk Sereh Wangi}

Persentase mortalitas harna bubuk Sitophilus oryzae dalam uji bubuk sereh wangi berdasarkan hasil analisis ragam menunjukan bahwa perlakuan berpengaruh sangat nyata dasi Waktu pengamatan 5 hari setelah aplikasi (HSA) sampai 30 hari setelah aplikasi (HSA). Persentase mortalitas dari setiap perlakuan bubuk sereh wangi, sejak pengamat hari ke-5 sampai han ke-30 setelah aplikasi, menunjukan adanya perbedaan dari setiap taraf perlakuan bubuk sereh wangi

Tabel 1. Uji beda rata-rata persentase mortalitas hama Sitophilus oryzae dari pengaruh perlakuan bubuk sereh wangi

\begin{tabular}{lcccccc}
\hline \multirow{2}{*}{ Perlakuan } & \multicolumn{5}{c}{ Hari Pengamatan Setealah Aplikasi (HAS) } \\
\cline { 2 - 6 } & 5 & 10 & 15 & 20 & 25 & 30 \\
\hline S1 (2,5 gr bubuk sereh wangi) & $10 \mathrm{c}$ & $15 \mathrm{c}$ & $22 \mathrm{c}$ & $32 \mathrm{c}$ & $43 \mathrm{c}$ & $56 \mathrm{c}$ \\
S2 (5,0 gr bubuk sereh wangi) & $16 \mathrm{~b}$ & $25 \mathrm{~b}$ & $31 \mathrm{~b}$ & $48 \mathrm{~b}$ & $67 \mathrm{~b}$ & $82 \mathrm{~b}$ \\
S3 (7,5 gr bubuk sereh wangi) & $24 \mathrm{a}$ & $34 \mathrm{a}$ & $46 \mathrm{a}$ & $64 \mathrm{a}$ & $82 \mathrm{a}$ & $96 \mathrm{a}$ \\
BNJ 0,05 & 2,5 & 3,3 & 4,3 & 6,0 & 8,8 & 7,6 \\
\hline
\end{tabular}

Keterangan: angka-angka yang diikuti dengan huruf yang berbeda pada kolom yang sama menunjukkan perbedaan yang nyata berdasarkan hasil uji BNJ pada taraf kepercayaan $0,05 \%$

Nilai rata-rata persentase mortalitas hama bubuk Sitophilus oryzae yang tertinggi sampai waktu pengamatan 30 HSA dihasilkan dari perlakuan bubuk sereh wangi 7,5 gr/100 gr benih padi, dimana persentase mortalitas yaitu sebesar 96\% (19 ekor hama Sitophilus oryzae mati). Rata-rata persentase mortalitas hama bubuk Sitophilus oryzae yang terendah dihasilkan oleh perlakuan bubuk sereh wangi 2,5 gr/100 gr benih padi, yaitu sebesar 56\% (11 ekor hama Sitophilus oryzae mati).

Berdasarkan hasil uji lanjut terhadap rata-rata persentase mortalitas hama bubuk Sitophilus oryzae memperlihatkan bahwa sejak pengamatan hari ke-5 sampai hari ke-30 setelah aplikasi, perlakuan S3 berbeda nyata dengan perlakuan S1, sedangkan untuk perlakuan S2 berbeda nyata dengan perlakuan S1. Rata-rata persentase mortalitas hama bubuk Sitophilus oryzae yang tertinggi dihasilkan dari perlakuan S3, hal ini menunjukan bahwa semakin banyak konsentrasi bubuk sereh wangi yang digunakan maka semakin tinggi pula komponen senyawa yang terkandung dalam minyak atsiri sereh wangi, sehingga lebih efektif dalam meningkatkan mortalitas hama bubuk Sitophilus oryzae. 


\section{Median Volume 11 Nomor 2 Bulan Juni 2019}

Doi http://doi.org/md.v11i2.550

\section{Total Mortalitas Hama Sitophilus oryzae dari Pengaruh Perlakuan Sereh Wangu Sampai Akhir Pengamatan}

Pengaruh perlakuan bubuk sereh wangi terhadap jumlah mortalitas hama bubuk Sitophilus oryzae, dari pengamatan 5 hari setelah aplikasi (HSA) sampai 30 HSA memperlihatkan adanya perbedaan dari setiap perlakuan. Jumlah tertinggi hama Sitophilus oryzae yang mati (ekor) sampai waktu pengamatan 30 hari setelah aplikasi dihasilkan dari perlakuan S3 (Gambar 1).

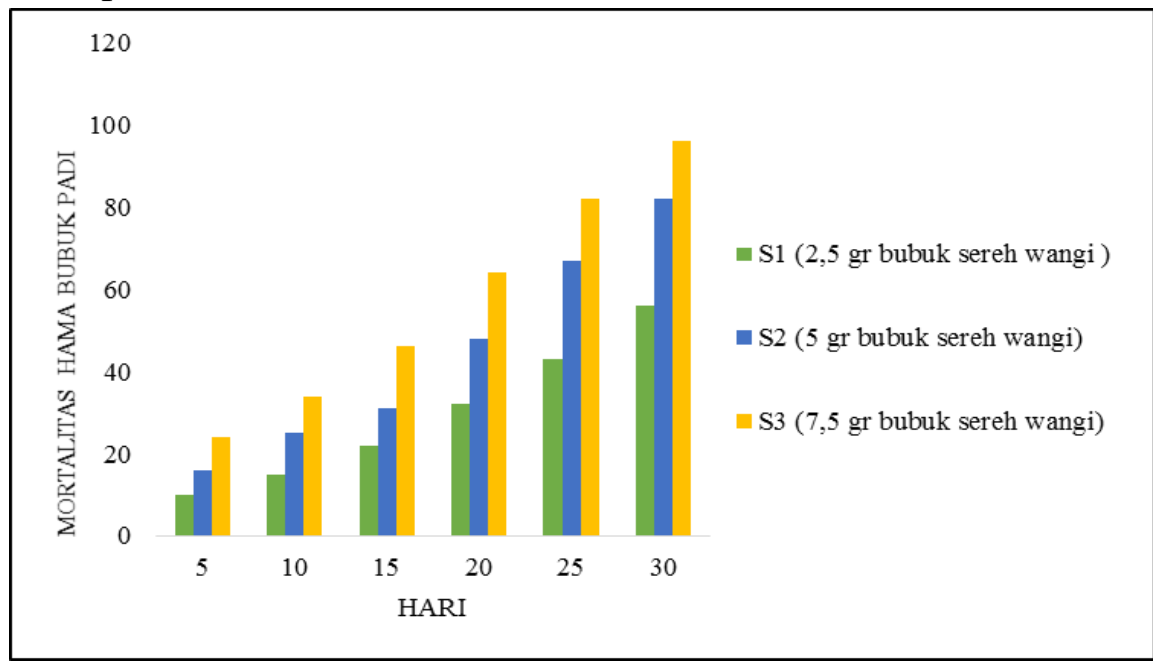

Gambar 1. Histogram Total Mortalitas Hama Sitophilus oryzae pada Pengamatan 5 sampai 30 HAS Bubuk Sereh Wangi.

Jumlah mortalitas hama Sitophilus oryzae berdasarkan Gambar 1, pada waktu pengamatan 5 HSA perlakuan S1 menghasilkan 2 ekor hama Sitophilus oryzae mati dari 20 hama uji, sedangkan pada perlakuan S2 menghasilkan 3 ekor hama Sitophilus oryzae mati dari 20 hama uji, dan untuk perlakuan S3 menghasilkan 5 ekor hama Sitophilus oryzae mati dari 20 ekor hama uji. Pada waktu pengamatan 30 HSA, perlakuan S3 menghasilkan 19 ekor hama Sitophilus oryzae mati dari 20 hama uji, sedangkan pada perlakuan S2 menghasilkan 16 ekor hama Sitophilus oryzae mati dari 20 hama uji, dan untuk perlakuan S1 menghasilkan 11 ekor hama Sitophilus oryzae mati dari 20 ekor hama uji.

Pengamatan mortalitas hama Sitophilus oryzae pada 10 HSA sampai 25 HSA memperlihatkan bahwa semakin banyak bubuk sereh wangi yang digunakan, akan menghasilkan jumlah mortalitas hama Sitophilus oryzae yang tertinggi.

\section{Rata-Rata Persentase Kehilangan Berat Benih Padi Setelah 30 Hari Perlakuan Bubuk Sereh Wangi}

Berdasarkan hasil analisis ragam terhadap persentase kehilangan berat benih padi sampai 30 HSA, perlakuan bubuk sereh wangi memperlihatkan perlakuan berpengaruh sangat nyata terhadap persentase kehilangan berat benih padi yang digunakan sebagai pakan untuk hama Sitophilus oryzae.

Tabel 2. Uji beda rata-rata persentase kehilangan berat benih padi dari pengaruh perlakuan bubuk sereh wangi terhadap hama Sitophilus oryzae 


\begin{tabular}{lc}
\hline Perlakuan & Persentase kehilangan berat benih (30 HSA) \\
\hline S1 (2,5 gr bubuk sereh wangi ) & $64,1 \mathrm{a}$ \\
S2 ( 5 gr bubuk sereh wangi) & $48,3 \mathrm{~b}$ \\
S3 (7,5 gr bubuk sereh wangi) & $30,7 \mathrm{c}$ \\
\hline BNJ 0,05 & 5,5 \\
\hline
\end{tabular}

Keterangan: angka-angka yang diikuti dengan huruf yang berbeda pada kolom yang sama menunjukkan perbedaan yang nyata berdasarkan hasil uji BNJ pada taraf kepercayaan 0,05\%

Persentase kehilangan berat benih padi dari perlakuan bubuk sereh wangi terhadap mortalitas hama Sitophilus oryzae menunjuukan persentase kehilangan berat benih padi yang tertinggi dihasilkan oleh perlakuan S1 dan persentase kehilangan berat benih padi terendah dihasilkan oleh perlakuan S3. Berdasarkan hasil uji lanjutan dengan menggunakan uji BNJ pada taraf 0,05\% menunjukkan bahwa perlakuan S1 berbeda nyata dengan perlakuan S2 dan sangat berbeda nyata dengan perlakuan S3. Gambaran kehilangan berat benih padi dari tiap perlakuan ditampilkan pada gambar 2 .

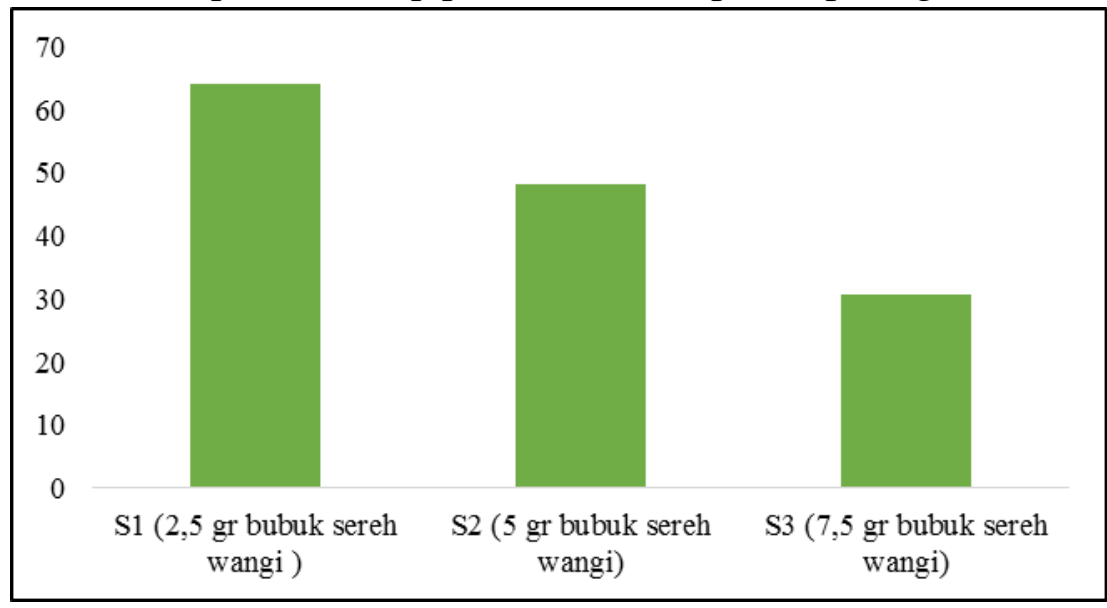

Gambar 2. Histogram Kehilangan berat benih padi (30 HAS)

\section{Pembahasan}

Penggunaan pestisida sintesis menimbulkan masalah residu kimia pada hahan tanaman, Akhir-akhir ini, pengendalian hama pada bahan pangan dalam penyimpanan beralih pada penggunaan bahan botani karena secara ekologis sangat cocok dan secara ekonomipun pengembangan sebagai bahan pengendalian serangga akan mudah diperoleh dan mudah terdegradasi sehingga tidak menimbulkan dampak residu pada bahan pangan dalam penyimpanan. Efektif tidaknya suatu insecktisida botani dapat dilahat berdasarkan banyaknya populasi hama yang hidup ataupun yang mati setelah perlakuan, ataupun bcrdasarkan kemampuan konsentrasi insektisida botani untuk mematikan hama uji sebesar 50\%. Menurut Kardinan (2013), efikasi adalah kemanjuran atau kemantapan daya bunuh insektisida nabati atau insektisida botani dalam membunuh jasad sasaran tertentu.

Berdasarkan hasil pengujian menunjukan bahwa semua tingkat perlakuan bubuk sereh wangi dapat mematikan hama bubuk padi Sitophilus oryzae. Namun rata-rata persentase mortalitas hama bubuk padi Sitophilus oryzae yang tertinggi dihasilkan oleh perlakuan 7,5 gr bubuk sereh wangi yaitu sebesar $96 \%$ atau 19 ekor hama uji mati dari 
20 ekor hama Sitophilus oryzae yang digunakan sebagai hama uji, sampai pengamatan hari ke-30 setelah aplikasi. Hal ini menunjukan bahwa semakin tinggi dosis bubuk sereh wangi yang digunakan akan menghasilkan tingkat persentase mortalitas hama Sitophilus oryzae yang lebih baik. Rata-rata persentase mortalitas hama Sitophilus oryzae yang terendah dihasilkan oleh perlakuan 2,5 gr bubuk sereh yaitu sebesar: 56\% (11 ekor hama mati dari 20 ekor hama Sitophilus oryzae uji). Hal ini dibuktikan dengan hasil uji lanjutan yang memperlihatkan perlakuan bubuk sereh wangi 7,5 gr berbeda nyata sampai berbeda sangat nyata dengan perlakuan dosis bubuk sereh wangi yang lainnya dari waktu pengamatan 5 hari setelah aplikasi sampai pada waktu pengamatan 30 hari setelah aplikasi (Tabel 1.). Dari hasil analisis ragam, perlakuan bubuk sereh wangi berpengaruh sangat nyata terhadap rata-rata persentase mortalitas hama Sitophilus oryzae dari waktu pengamatan 5 hari setelah aplikasi sampai 30 hari setelah aplikasi.

Persentase mortalitas hama Sitophilus oryzae sudah tcrjadi pada pengamatan hari ke-5 dan semakin meningkat sampai pengamatan hari ke-30 setelah aplikasi bubuk sereh wangi, tetapi rata-rata persentase mortalitas hama Sitophilus oryzae yang tertinggi dihasilkan oleh perlakuan bubuk sereh wangi 7,5 gram sejak hari ke-5 sampai hari ke-30 setelah aplikasi. Hal ini membuktikan bahwa semakin besar dosis bubuk sereh wangi yang digunakan menghasilkan persentase mortalitas hama Sitophilus oryzae yang lebih baik, karena kandungan bahan aktif dari minyak atsiri sereh wangi yang terdiri dari senyawa silikal, sitral, sitronella, geraniol, mirsenal, nerol, farsenol, mehtal heptenon dan diptena, banyak terdapat pada dosis 7,5 gr bubuk sereh wangi. Senyawa aktif yang terdapat dalam tanaman sereh wangi bersifat insektida dan toksik terhadap serangga sehingga dapat mematikan hama Sitophilus oryzae, karena senyawa-senyawa tersebut mempunyai tipe mekanisme pengendalian insektisidal bersifat racun kontak. Menurut Kardinan (2010), kandungan senyawa yang terdapat pada tanaman sereh wangi dapat bersifat sebagai penyebab desikasi pada tubuh serangga, apabila serangga terluka maka serangga tersebut akan terus menerus kehilangan cairan tubuhnya dan selanjutnya mengalami kematian dan juga merupakan bahan beracun yang dapat bekerja sebagai racun perut dan fumigan yang akan menguap dan menembus secara langsung ke integument serangga.

Kandungan senyawa dalam tanaman sereh wangi selain sifat kerjanya sebagai racun kontak yang dapat menyebabkan desikasi pada tubuh serangga dan mengakibatkan mortalitas, senyawa ini pula mempunyai sifat kerja sebagai racun perut, dimana senyawa aktif tersebut masuk ketubuh serangga melalui mulut (oral) dan dapat menimbulkan mortalitas lebih tinggi karena kandungan senyawa yang terdapat dalam minyak atsiri sereh wangi bersifat insektisidal yang masuk melalui sistem pencernaan Sitophilus oryzae. Hal ini dapat dibuktikan dengan rata-ma persentase mortalitas yang lebih besar dari dosis 7,5 gram bubuk sereh wangi, dimma diduga bahwa semakin besar dosis yang digunakan semakin bayak pula kandungan senyawa aktif dalam bubuk sereh wangi tersebut sehingga mampu menimbulkan desikasi pada tubuh serangga dan bersifat racun perut sehingga mortalitas hama Sitophilus oryzae semakin tinggi. Menurut Surtikanti (2010), bahwa tingkat dosis senyawa botanis yang banyak 
kandungan senyawa aktif mempunyai pengaruh yang ditimbulkan semakin tinggi, disamping itu daya kerja racun suatu senyawa sangat ditentukan oleh besarnya dosis. Menurut Solichah dan Poerwanto (2007), bahwa senyawa-senyawa yang terdapat dalam minyak atsiri sereh wangi diduga tidak terurai atau mengalami perubahan ke bentuk senyawa yang lebih beracun oleh berhagai jenis enzim yang ada pada sistem pencernaan serangga sehingga dapat meningkatkan jumlah serangga yang mati.

Selain sifat kerja dari senyawa yang terkandung dalam bubuk sereh wangi yang bersifat racun kontak dan racun perut, senyawa ini pula dapat beketja sebagai racun saraf. Hasil pengujian menunjukan bahwa perlakuan dengan dosis 7,5 gram bubuk sereh wangi menghasilkan rata-rata persentase mortalitas yang lebih besar dari perlakuan yang lain. Hal ini diduga bahwa semakin besar dosis yang digunakan maka kandungan senyawa aktif dalam bubuk sereh wangi semakin banyak dan dapat bekerja sebagai racun saraf sehingga mampu menimbulkan mortalitas hama Sitophilus oryzae melalui sistem pemafasan. Cremlyn (1991), menyatakan bahwa senyawa minyak atsiri dari tanaman sereh wangi dapat bekerja sebagai racun syaraf pada serangga. Hal ini dapat dilihat dari gejala keracunannya seperti terjadi eksitasi, kejang, tubuh menjadi lemah dan akhirnya mati. Senyawa minyak atsiri sereh wangi dapat menyerang syaraf serangga khususnya saraf otot yang menyebabkan saraf ini tidak aktif akibatnya serangga mati. Mekanisme penetrasi senyawa tersebut diawali dengan penembusan membran sel oleh nikotin, kemudian mengikat reseptor acetycoline pada sambungan saraf otot akibatnya terjadi tarikan saraf sehingga saraf rusak atau tidak berfungsi yang menyebabkan kematian.

Selain sifat kerja dari senyawa aktif yang terkandung dalam bubuk sereh wangi sebagai racun kontak, racun perut, dan racun pernapasan, senyawa ini pula dapat bersifat antifeedan (menghambat aktivitas makan) sehingga dapat mengakibatkan hama Sitophilus oryzae tidak makan dan berakibat kepada kematian hama tersebut. Diduga kandungan bahan aktif dari bubuk sereh wangi yaitu senyawa silikal, sitral, sitronella, geraniol, mirsenal, nerol, farsenol, mehtal heptenon dan diptena, yang banyak terdapat pada dosis 7,5 gram bubuk sereh wangi dapat bersifat antifeedan sehingga dapat menghambat aktivitas makan dari hama Sitophilus oryzae, sehingga dapat mengakibatkan mortalitas lebih besar. Menurut Santoso (2007), bahwa senyawa geraniol, farsenol dan senyawa mehtal heptenon termasuk diptena, memberikan bau yang khas sehingga dapat mengakibatkan serangga tidak akan makan pada bahan tanaman yang telah diperlakukan dengan senyawa-senyawa tersebut. Berdasarkan hasil pengujian, senyawa yang terkandung dalam bubuk sereh wangi pada dosis 7,5 gram menghasilkan rata-rata mortalitas yang tinggi serta persentase kehilangan berat akhir benih padi sangat sedikit yaitu hanya sebesar 30,7\% sampai waktu pengamatan 30 hari setelah aplikasi. Hal ini membuktikan bahwa mortalitas hama Sitophilus oryzae selain dari sifat kerja senyawa sereh wangi sebagai racun kontak, racun perut dan racun pernapasan juga bersifat antifeedan sehingga hama Sitophilus oryzae tidak makan dan seterusnya akan mati. 


\section{Median Volume 11 Nomor 2 Bulan Juni 2019}

Doi http://doi.org/md.v11i2.550

\section{KESIMPULAN}

Berdasarkan hasil penelitian yang telah dilakukan, maka dapat ditarik kesimpulan bahwa semua perlakuan dosis bubuk sereh wangi mampu mematikan hama bubuk Sitophilus oryzae sejak dari hari ke-5 setelah aplikasi sampai hari ke-3O setelah aplikasi. Perlakuan dosis bubuk sereh wangi 7,5 gr/100 gr benih padi, merupakan dosis bubuk sereh wangi yang terbaik dalam meningkatkan rata-rata persentase mortalitas hama bubuk Sitophilus oryzae. Sampai pada waktu pengamatan hari ke-30 setelah aplikasi, menghasilkan rata-rata. Selain itu, perlakuan dosis bubuk sereh wangi 7,5 gr mampu menurunkan persentase kehilangan berat akhir dari benih padi, dimana sampai pengamatan hari ke-30 setelah aplikasi kehilangan berat benih padi hanya sebcsar 30,7\%. Sedangkan persentase kehilangan bobot akhir benih padi yang tertinggi dihasilkan oleh perlakuan dosis bubuk sereh wangi 2,5 gram, dimana sampai hari ke-30 setelah aplikasi persentase kchilangan berat benih padi sebesar $64,1 \%$.

\section{DAFTAR PUSTAKA}

Anggara, A.W. 2011. Hama Gudang Penyimpanan Padi. Pusat Penelitian dan Pengembangan Tanaman Pangan. Puslitbangtan. Jawa Barat.

Cremlyn, R.J.W. 1991. Agrochemicals Preparation and Mode of Action. New York: John Wiley and Sons New York, p: 54-55.

Kardinan, A. 2010. Pestisida Nabati, Ramuan, dan Aplikasi. Penerbit Rineka Cipta. Jakarta.

Oka, I.N. 2003. Penggunaan, Permasalahan, serta Prospek Pestisida Nabati dalam Pengendalian Hama Terpadu. Prosiding Seminar Hasil Penelitian dalam Rangka Pemanfaatan Insektisida Nabati. Balittro Bogor.

Pracaya. 2011. Hama dan Penyakit Tanaman. Penerbit Penebar Swadaya. Jakarta.

Prasetyo. 2011. Budidaya Tanaman Padi. Penerbit Kanisius. Yogyakarta.

Rukmana, H.R. 2007. Usaha Tani Padi. Penerbit Kanisius. Yogyakarta.

Surtikanti. 2010. Pengendalian Kumbang Bubuk Sitophilus zeamays dengan Mengunakan Senyawa Kimia Botanik. Jurnal Litbang Pertanian, 23(4):123-128.

Wiratno, Siswanto, Luluk, dan Suriati, S. 2011. Efektivitas Beberapa Jenis Tanaman Obat dan Aromatik sebagai Insektisida Nabati untuk Mengendalikan Diconocoris hewetti Dist. Bul. Littro. 22 (2): 198-204.

Yasin, M. 2009. Kemampuan Akses Makan Serangga Hama Kumbang Bubuk dan Faktor Fisikokimia yang Mempengaruhinya. Prosiding Seminar Nasional Serealia 2009. ISBN: 978-979-8940-27-9. Balai Tanaman Serealia. 